
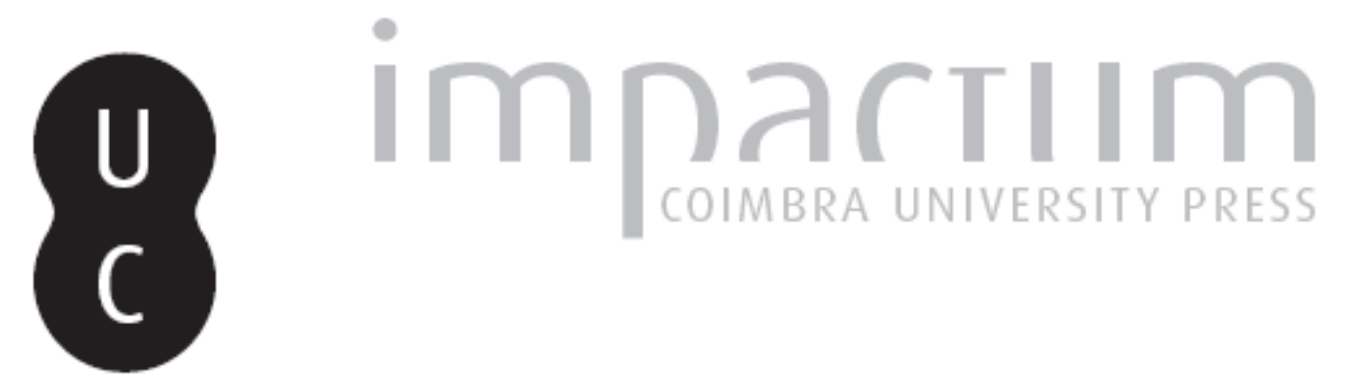

\title{
Paleopathological evaluation of Hungarian skeletal remains from the 7th-9th centuries AD
}

Autor(es): $\quad$ Molnár, Erika; Marcsik, Antónia

Publicado por: CIAS - Centro de Investigação em Antropologia e Saúde

URL persistente:

URI:http://hdl.handle.net/10316.2/41264

DOI:

DOI:http://dx.doi.org/10.14195/2182-7982_19_8

Accessed : $\quad$ 26-Apr-2023 04:55:55

A navegação consulta e descarregamento dos títulos inseridos nas Bibliotecas Digitais UC Digitalis, UC Pombalina e UC Impactum, pressupõem a aceitação plena e sem reservas dos Termos e Condições de Uso destas Bibliotecas Digitais, disponíveis em https://digitalis.uc.pt/pt-pt/termos.

Conforme exposto nos referidos Termos e Condições de Uso, o descarregamento de títulos de acesso restrito requer uma licença válida de autorização devendo o utilizador aceder ao(s) documento(s) a partir de um endereço de IP da instituição detentora da supramencionada licença.

Ao utilizador é apenas permitido o descarregamento para uso pessoal, pelo que o emprego do(s) título(s) descarregado(s) para outro fim, designadamente comercial, carece de autorização do respetivo autor ou editor da obra.

Na medida em que todas as obras da UC Digitalis se encontram protegidas pelo Código do Direito de Autor e Direitos Conexos e demais legislação aplicável, toda a cópia, parcial ou total, deste documento, nos casos em que é legalmente admitida, deverá conter ou fazer-se acompanhar por este aviso.

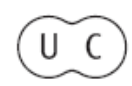


Antropologia Portuguesa

Volume $19 \cdot 2002$

Departamento de Antropologia | Universidade de Coimbra 


\title{
Paleopathological evaluation of Hungarian skeletal remains from the $7^{\text {th }}-9^{\text {th }}$ centuries $A D$
}

\author{
Erika Molnár, Antónia Marcsik \\ Department of Anthropology \\ University of Szeged \\ H-6701 Szeged Pf. 660, Hungary \\ balinte@bio.u-szeged.hu
}

Abstract The Avars are one of the most remarkable populations of the Migration Period in the Carpathian basin. The $7^{\text {th }}-9^{\text {th }}$ century series of Szarvas represents an outstanding example of Avar age skeletal populations with grave goods, like a runic scripted needle-case. Our attention was directed to this series by the relatively high number of linear hypoplasias, detected in a previous study. The macromorphological examination of the 423 skeletons was completed with radiological and, in a few cases, with paleomicrobiological analyses. Special attention was paid to infectious alterations, particularly to TB, which usually has a relatively high prevalence in this period. Our sample also shows a high number of infectious changes, including some potential tuberculous alterations. However, classic, advanced stage TB cases could not be found in the series. The detected alterations are rather atypical, early stage forms, observed mainly in children and young adults, often in association with other post-cranial pathological conditions. However, the diagnosis of tuberculosis was also supported by the biomolecular results in an elderly male individual, showing calcified pleura remains. Besides infections, the presence of some rarely reported pathological conditions, such as "butterfly" vertebra and hyperostosis frontalis interna, are worth mentioning.

Key words Paleopathology; infectious changes; tuberculosis; "butterfly" vertebra; hyperostosis frontalis interna; Hungary.

Resumo Os Avars são uma das mais notáveis populaçōes do Período Migração na bacia Carpática. As séries dos séculos VII-IX de Szarvas representam um exemplo excepcional de populações da Idade Avar com oferendas nas sepulturas como seja um agulheiro com inscrição rúnica. A nossa atenção foi direccionada para esta série pelo número relativamente alto de hipoplasias lineares detectado num prévio estudo. O exame 
macro-morfológico dos 423 esqueletos foi complementado com o radiológico e, nalguns casos, com análise paleomicrobiológica. Uma atenção especial foi dada às alteraçōes infecciosas, particularmente à tuberculose, as quais frequentemente têm uma prevalência relativamente alta neste período. A nossa amostra também apresenta um grande número de alterações infecciosas, incluindo algumas potenciais alteraçōes tuberculosas. No entanto, não foram encontrados estádios avançados e clássicos de tuberculose; as alterações detectadas são mais atípicas, são formas de estádios iniciais e foram observadas, maioritariamente, em crianças e jovens adultos, frequentemente em associação com outras patologias pós-cranianas. De salientar que o diagnóstico de tuberculose foi corroborado por resultados biomoleculares num indivíduo masculino idoso que apresentava restos de pleura calcificada. Para além destas infecções, a presença de outras patologias raramente reportados, tais como a vértebra "borboleta" e a hiperostose frontal interna merecem também ser descritas.

Palavras-chave Paleopatologia; alterações infecciosas; tuberculose; vértebra "borboleta"; hiperostose frontal interna; Hungria.

\section{Introduction}

The people and ethnic groups that lived in the Carpathian basin during the Avar period (between 568 and 800-850 AD) are highly important for the population history of the Middle Ages (Lipták, 1983). The $7^{\text {th }} 9^{\text {th }}$ century AD series of Szarvas represents an outstanding example of Avar period skeletal populations showing burial rites, such as horse-interment and grave goods, like the runic scripted needle-case revealed in the proximity of one of the female individuals (Szentpéteri, 2002). The scarcity of written sources from this period makes this cemetery very important from an archaeological point of view.

Our attention has been directed to this series by the relatively high number of linear hypoplasia, detected in a previous work (Molnár and Horváth, 1995).

The purpose of the current study was the paleopathological analysis of the Avar age sample of Szarvas. Special attention was paid to infectious alterations, particularly to TB, which usually has 
a relatively high prevalence in Avar age series (Molnár et al., 1998; Pálfi and Marcsik, 1999).

\section{Material and methods}

The material for this study comes from an archaeological site situated near Szarvas (a small town in South-Eastern Hungary), where a long-running excavation (1983-1986) was carried out under the direction of Irén Juhász. The excavation yielded 423 human skeletons, which are housed in the collection of the Department of Anthropology, University of Szeged, Hungary.

The demographic profile of the series was determined on the basis of the method by Ferembach et al. (1979) as the following: 150 males, 136 females, 39 juveniles, 93 infants and 5 undeterminable adults (Figure 1).

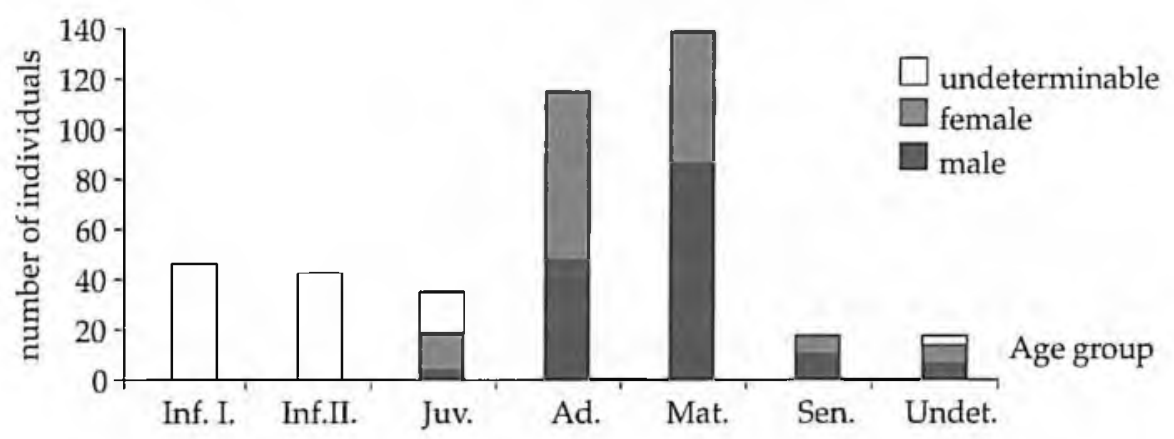

Figure 1. Distribution of the age and sex in the series of Szarvas.

Concerning pathological conditions (Steinbock, 1976; Zimmerman and Kelley, 1982; Ortner and Putschar, 1985; Resnick and Niwayama, 1988; Aufderheide and Rodríguez-Martín, 1998), the macro-morphological examination of the unearthed 423 skeletons was completed with radiological, and in few cases, with paleomicrobiological analyses (Haas et al., 2000).

During the examination of the series, the state of preservation of the observable skeletal elements was noted according to a five degree scale (Dutour, 1989; Bello, 2000). 


\section{Results and discussion}

\section{State of preservation}

The studied osteoarchaeological material is characterized by a rather poor state of preservation. As can be seen in Figure 2, the best preserved skeletons (where more than $80 \%$ of the skeleton could be observed) present only $3 \%$ of the examined sample.

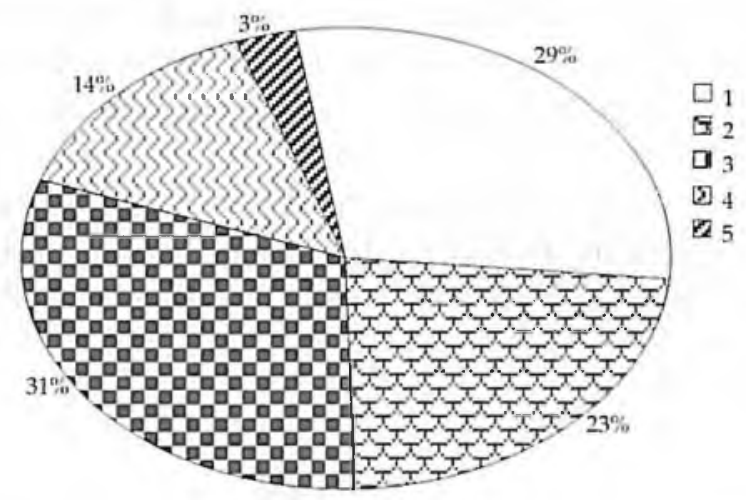

Figure 2. State of preservation in the skeletal sample of Szarvas according to a 5-grade scale.

Remarkable differences could be noted in the preservation of the different skeletal elements, such as the frequent absence of ribs and vertebral columns. It has to be mentioned that the spine in 169 cases, while the ribs in 223 cases, were missing. Furthermore subadult and female skeletons proved to be more fragile than adult and male bones.

\section{Paleopathological analysis}

The skeletal remains presented a wide range of pathological changes, among which trauma, haematological and metabolic disorders, as well as degenerative joint and spinal alterations have a similar representation in the series of Szarvas, like in other Avar age samples (Marcsik, 1985; Molnár, 2000). As usual, degenerative changes could be seen most frequently in the series, concerning both spinal (131/291 adults) and extra-vertebral (75/291 adults) localizations. Trauma was also relatively often observed, especially in males (34 of 
423 individuals, among which 28 were males). However, traces of haematological and metabolic disorders were not often detected and were, respectively, $4.0 \%(17 / 423)$ and $2.4 \%(10 / 423)$.

Among the observed skeletal lesions, a relatively high number of probable infectious alterations were revealed. Traces of potential infectious conditions were recognized in 89 cases. Furthermore, the series provided examples to some rarely documented pathological conditions, such as 'butterfly' vertebra and hyperostosis frontalis interna.

\section{Infectious conditions}

The majority of the detected infectious alterations ( 79 cases) can be considered non-specific. The most frequent changes consist of periosteal alterations observed on long bones (23 specimens). Although the inflammatory conditions of the periosteum are often associated with infection, it is important to emphasize that it may be caused by other pathological conditions, too.

There were also several types of endocranial alterations observed in the studied skeletal material. Although a certain classification of macro-morphological changes in the endocranial lamina is possible (such as, whitish coloration and periosteal plaques, abnormal blood vessel and granular impressions, and maze-like changes (e.g. Schultz, 2001; Hershkovitz et al., 2002), their unambiguous categorization for aetiology cannot be done without further examination. Therefore, in the present study the detected 17 cases were diagnosed as non-specific infectious alterations (Figure 3), particularly since they do not show further osseous changes in favour of a specific aetiology.

However, other infectious alterations, such as osteomyelitis (Figure 4), sinusitis and articular lesions, were also detected in the series. Concerning articular lesions, it was the sacroiliac joint which was the most often affected with inflammatory alterations. 


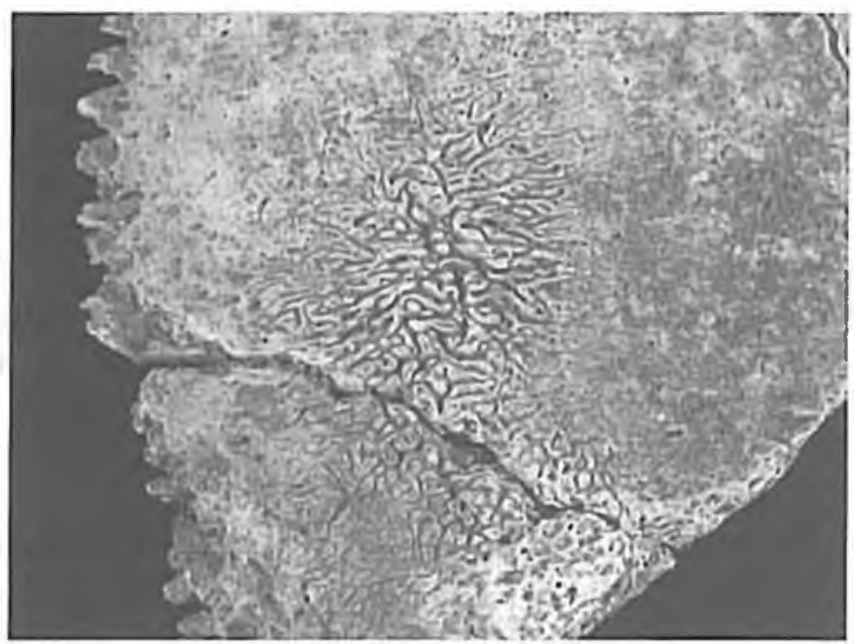

Figure 3. Discolored areas and abnormal blood vessel impressions in the endocranial plate (Grave No. 389, adult, male, parietal bone).

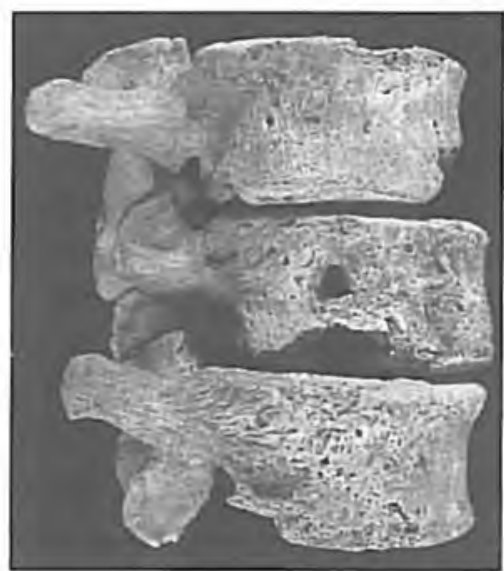

Figure 4. Vertebral osteomyelitis (Grave No. 210, young adult, male, lumbar vertebrae).

We have to note that the above mentioned lesions were often accompanied by stress markers, such as cribra orbitalia and linear enamel hypoplasia the prevalence of which was relatively high (29\%) in the skeletal population of Szarvas (Molnár and Horváth, 1995).

Regarding specific infections, some minor alterations supposedly to indicate TB could be observed in the examined skeletal material.

The skeletal pattern and association of these lesions (e.g. periosteal apposition on the visceral surface of ribs, endocranial changes and multiple smooth walled resorptive lesions on the anterior aspect of vertebral bodies) suggested the diagnosis of tuberculosis in 10 individuals. Furthermore, these alterations were noted more often in younger age groups, especially in young adults. As an example we can mention a young adult female skeleton (Sza-421) 
showing several pathological conditions. Among others, slight periosteal apposition could be observed on the visceral surfaces of the rib fragments. Multiple smooth walled resorptive lesions on the anterior aspect of the $11^{\text {th }}$ and $12^{\text {th }}$ thoracic vertebrae were also detected. Moreover, a serpentine branching surface excavation of the endocranial lamina, termed as SES, occurred in the frontal bone (Figure 5) and along both sides of the sagittal suture in the parietal bones (Hershkovitz et al., 2002). The co-occurrence of the above mentioned lesions, supporting the idea of a tuberculous aetiology, has already been illustrated in several studies (Maczel et nl., 2001; Mays et al., 2002; Pálfi, 2002).

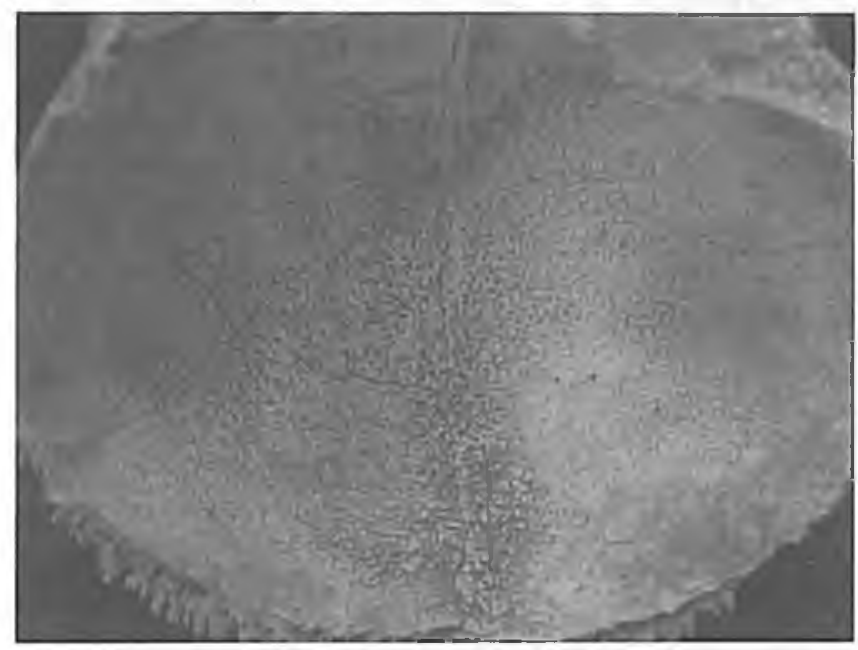

Figure 5. Maze-like changes in the endocranial lamina (Grave No. 421, young adult, female, frontal bone).

As mentioned above, the status of minor endocranial lesions is controversial in paleopathology. However, the aetiology of the smooth walled resorptive lesions on the vertebral bodies and the periosteal apposition on the visceral surface of ribs has been discussed extensively (e.g. Baker, 1999; Kelley and Micozzi, 1984; Roberts et al., 1994; Santos and Roberts, 2001). However, their cooccurrence (eventually with further bony signs of infection) may be viewed as supporting the idea that they are manifestations of tuberculosis. According to the study of Mays and colleagues (2002) 
further work on other skeletal material showing these changes, supported by aDNA analysis, is needed in order to properly evaluate the status of these lesions as indicators of tuberculosis in paleopathology.

On the basis of calcified pleura remains, the diagnosis of tuberculosis was also suspected in two old male individuals (Figure 6). The detection of Mycobncterium tuberculosis complex DNA (using the $123 \mathrm{bp} \mathrm{PCR} \mathrm{product} \mathrm{of} \mathrm{the} \mathrm{IS6110} \mathrm{sequence)}$ supported the diagnosis of TB in one of these two skeletons showing calcified soft tissues. We have to note that the positive PCR results do not prove a direct association between the tuberculous infection and the pleura calcification, but provide supporting evidence for the diagnosis of TB.

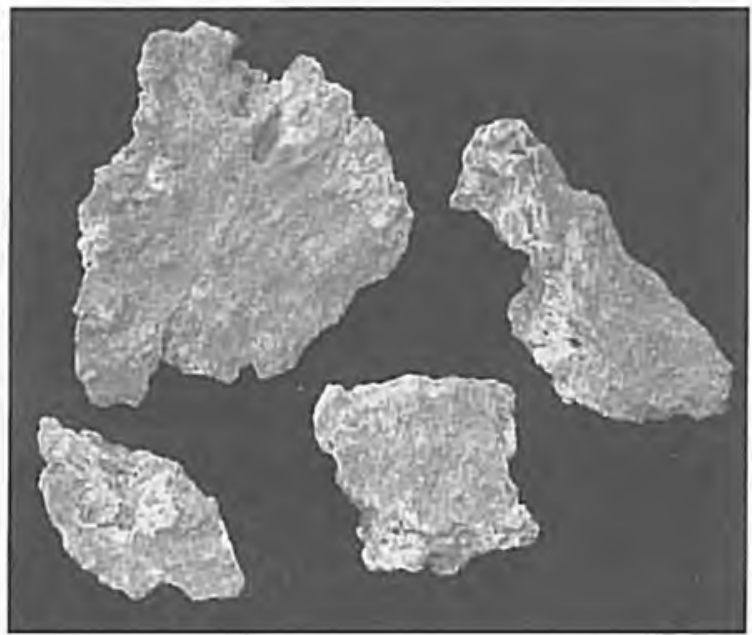

Figure 6. Calcified pleura (Grave No. 368, adult, male).

The biomolecular analysis of the other supposed TB cases is a future objective. Nevertheless, we have to emphasize that almost all of the detected potential tuberculous cases come from the so-called late Avar age ( $8^{\text {th }}-9^{\text {th }}$ centuries), where severe climate changes in the Great Hungarian Plain have been hypothesised by Györffy and Zólyomi (1994), probably resulting in starvation and challenging the immune system of the populations living in this area. 


\section{Developmental anomalies}

Several types of developmental anomalies, mainly congenital spine and hip defects, were recognized in the series: altogether there were 36 developmental defects belonging to 31 individuals.

Among them, the presence of a rare congenital malformation of the spine, known as 'butterfly' vertebra, is worth mentioning. This anomaly appears in the early embryonic period, when the notochord begins to regress. Normally the notochordal material expands the intradiscal space and gradually disappears from the centre. However, defective intradiscal migration of notochordal cells and failure of the notochord to recede from a developing vertebral segment can prevent the fusion of the lateral halves of the cartilaginous vertebral bodies. This process results in a bifid centre - or 'butterfly' vertebra (Barnes, 1994).

This malformation usually occurs in the thoracic and lumbar spine and males are generally more often affected than females (Barnes, 1994; Aufderheide and Rodríguez-Martín, 1998). Concerning osteoarchaeological material only a few cases are reported in the literature (e.g. Merbs and Willson, 1962; Barnes, 1994; Brasili et al., 2002).

In our material the above described sagittal cleft vertebra was observed in the thoracic spine of an adult male individual (Sza189). The two halves of the $11^{\text {th }}$ thoracic vertebral body are almost equal in size, but a slight hypoplasia of the right half could be detected (Figure 7). The separation of vertebral halves is incomplete; a bony bridge connects the two parts of the anteriorly wedged-shaped vertebral body (Figure 8). The

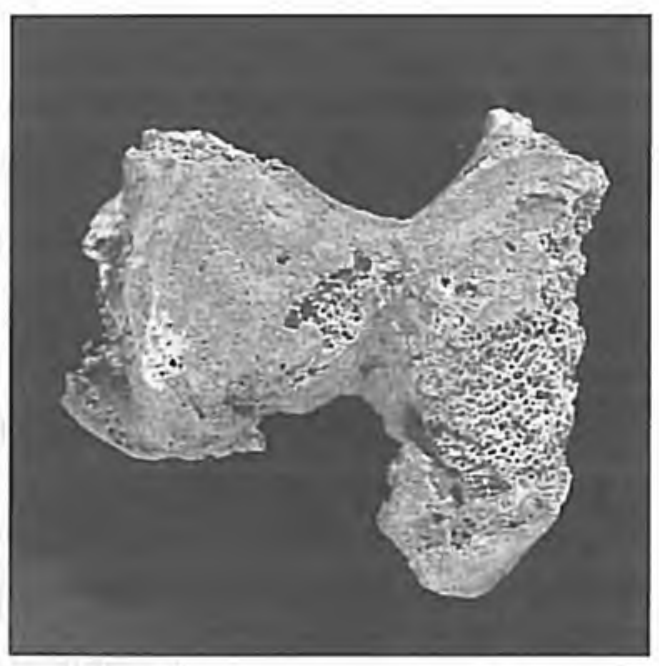

Figure 7. Sagittal cleft vertebra - superior view (Grave No. 189, adult, male, $17^{\text {th }}$ lumbar vertebra). 


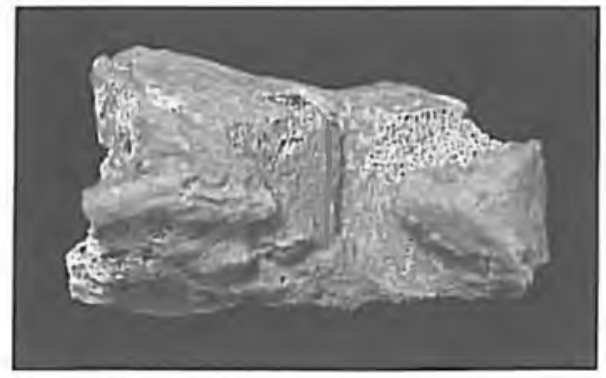

Figure 8. Sagittal cleft vertebra - anterior view (Grave No. 189, adult, male, $11^{\text {th }}$ lumbar vertebra).

'butterfly' vertebra resulted in kyphosis due to the diminished anterior height of the vertebral body, presumably causing back pain after carrying or heavy lifting for the affected individual during his life.

\section{Other anomalies}

Hyperostosis frontalis interna (HFI), first described by Morgagni in 1719 (in Hershkovitz et al., 1999), is manifested by bone accretion on the inner table of the frontal bone. HFI is supposed to be an independent condition and not a sign of a more generalized syndrome as suggested in the past. It can appear in a variety of forms, but each is the result of the same process and probably of the same aetiology. It is most commonly found among females and is believed to be associated with prolonged oestrogen stimulation. The phenomenon is associated with age insofar as it is more frequent in females over 40 years (Hershkovitz et al., 1999).

HFI is rarely reported in the paleopathological literature (e.g. Armelagos and Chrisman, 1988; Hershkovitz et al., 1999; Buzhilova and Kozlovskaya, 2001). In the examined osteoarchaeological material, bilateral new bone formation was detected by direct observation on the endocranial surface of the frontal bone in 6 of the 423 skeletons. Of the 6 specimens, 4 showed slight, while 2 moderate bony overgrowths on the antero-medial part of the frontal bone (Figure 9). The affected skulls were radiographed applying lateral radiography.

Concerning the sex distribution, this alteration was revealed in 5 females and 1 male. According to age, the endocranial plate of 4 mature and 1 elderly individuals showed the above mentioned lesions, which were diagnosed as possible cases of hyperostosis frontalis interna (Barber et al., 1997; Hershkovitz et al., 1999; Ortner, 2003). 


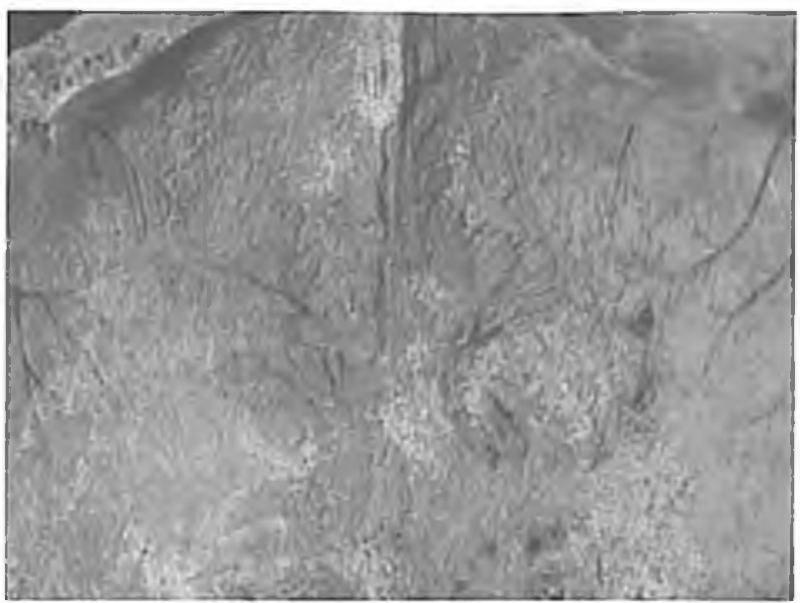

Figure 9. Probable case of hyperostosis frontalis interna (Grave No. 244, adult, female).

\section{Conclusion}

In spite of the poor state of the preservation, the osteoarchaeological series of Szarvas shows a wide range of paleopathological alterations, and also including some rarely observable lesions. This fact draws the attention to the importance of the examination of fragmentary skeletal samples.

Similarly to other Avar age samples, degenerative changes (both in the vertebral column and extra-vertebral locations) and trauma (showing a male predominance) were the most frequently detected conditions in our material. The fact that these alterations could be observed more frequently and in more localizations among males refers to a probable division of labour in the series of Szarvas (as pointed out in the case of other Avar age samples).

Beside degenerative changes, infectious alterations could also often be seen in the series. Taking into consideration the dating of the potential tuberculous cases, the relatively high number of further infectious alterations might also be related to the worsening of environmental conditions in the late Avar age. The relatively high frequency of linear enamel hypoplasia seems to support this hypothesis, too. The archaeological refinement of the graves' dating, i.e. the differentiation of the $7^{\text {th }}, 8^{\text {th }}$ and $9^{\text {th }}$ century 
parts of the cemetery, would contribute to the detection of supposed differences in the infectious affliction of the population of Szarvas living in the early, middle and late Avar periods.

However, for the utilization of the current study's results in future comparative paleoepidemiological studies, the calculation of corrected prevalence of the different pathological conditions as suggested by Waldron (1999) is needed.

\section{Acknowledgement}

This research was supported by the National Research Foundation (OTKA grant no. D 38476) and the Széchenyi Grant (no. 5/081). The authors are also indebted to Prof. Andreas Nerlich and Dr. Albert Zink (Institute of Pathology, Academic Hospital, MunichBogenhausen, Germany) for the paleomicrobiological analysis of bone samples.

\section{Bibliography}

Armelagos, G. J.; Chrisman, O. D. 1988. Hyperostosis frontalis interna: a Nubian case. American Journal of Physical Anthropology, 76(1): 25-28.

Aufderheide, A. C.; Rodriguez-Martín, C. 1998. The Cambridge Encyclopaedin Of Human Palcopathology. Cambridge, Cambridge University Press.

Baker, B. M. 1999. Early manifestations of tuberculosis in the skeleton. In: Pálfi, Gy; Dutour, O.; Deák, J.; Hutás, I. (eds.) Tuberculosis: past and present. Budapest - Szeged, Golden Book - TB Foundation: 299-307.

Barber, G.; Watt, I.; Rogers, J. 1997. A comparison of radiological and palaeopathological diagnostic criteria for hyperostosis frontalis interna. International Joumal of Osteonrchaeology, 7(2): 157-164.

Barnes, E. 1994. Developmental defects of the axinl skeleton in palcopathology. Colorado, University Press of Colorado.

Bello, S. 2000. Taphonomie des restes osseux humnins. Effet des processus te consernation du squelette sur les parmètres anthropologiques. PhD thesis. Università degli Studi di Firenze, Université de la Méditerranée-AixMarseille II, Faculté de Médecine. 
Brasili, P.; Bonfiglioli, B.; Ventrella, A. R. 2002. A case of 'butterfly' vertebra from Sardinia. International jommal of Osteonchaeology, 12(6): 415-419.

Buzlilova, A.; Kozlovskaya, M. 2001. Hyperostosis frontalis interna in Scythians of Middle Don Region, Russia. In: Verghetta, M.; Capasso, L. (eds.). Procecdings of the XIIIth Europenn Meting of the Paleopnthology Associntion. Teramo, Edigrafital S.p.A.: 57-60.

Dutour, O. 1989. Hommes fossiles du Salara. Peuplement Holocène du Mali septentrional. Paris, Éditions du CNRS.

Ferembach, D.; Schwidetzky, I.; Stloukal, M. 1979. Recommandations pour déterminer l'âge et le sexe sur le squelette. Bulletins et Mémoires de la Société d'Anthropologie de Paris, 6(13): 7-45.

Györffy, Gy.; Zólyomi, B. 1994. A Kárpát-medence és Etelköz képe egy évezred elött. In: Kovács, L. (ed.). Honfoglalís és régészet. Budapest, Balassi Kiadó: 13-39.

Haas, C. J.; Zink, A.; Molnár, E.; Szeimies, U.; Reisch1, U.; Marcsik, A.; Ardagna, Y.; Dutour, O.; Pálfi, Gy.; Nerlich, A.G. 2000. Molecular evidence for different stages of tuberculosis in ancient bone samples from Hungary. American Journal of Plysical Anthropology, 113(3): 293304.

Hershkovitz, I.; Greenwald, C.; Rothschild, B. M.; Latimer, B.; Dutour, O.; Jellema, L. M.; Wish-Baratz, S. 1999. Hyperostosis frontalis interna: an anthropological perspective. American Joumal of Physical Anthropology, 109(3): 303-325.

Hershkovitz, I.; Greenwald, C. M.; Latimer, B.; Jellema, L. M.; WishBaratz, S.; Eshed, V.; Dutour, O.; Rothschild, B. M. 2002. Serpens Endocrania Symmetrica (SES): a new term and a possible clue for identifying intrathoracic disease in skeletal populations. Americnn Joumal of Pluysical Anthropology, 118(3): 201-216.

Kelley, M. A.; Micozzi, M. S. 1984. Rib lesions in chronic pulmonary tuberculosis. Amterican fonmal of Physical Anthropology, 65(4): 381-386. Lipták, P. 1983. Avnrs ant ancient Hungarinns. Budapest, Akadémiai Kiadó. Maczel, M.; Ardagna, Y.; Aycard, P.; Bérato, J.; Zink, A.; Nerlich, A. G.; Panuel, M.; Dutour, O.; Pálfi, Gy. 2001. Traces of skeletal infections in a French medieval osteoarchaeological sample (La Celle, Var, France). In: Verghetta, M.; Capasso, L. (eds.). Proccedings of the XIIIth Europenn Mecting of the Paleopathology Associntion. Teramo, Edigrafital S.p.A.: 167-177.

Marcsik, A. 1985. Paleopathology of the Avar age between the Danube and Tisza rivers. Actn Biologica Szeget, 31: 191-196. 
Mays, S.; Fysh, E.; Taylor, G. M. 2002. Investigation of the link between visceral surface rib lesions and tuberculosis in a Medieval skeletal series from England using ancient DNA. American Joumal of Plysical Anthropology, 119(1): 27-36.

Merbs, C. F.; Willson, W. H. 1962. Anomalies and pathologies of the Sadlermiut Eskimo vertebral column. National Musetum of Conada, 180: 154-180.

Molnár, E. 2000. Egy avar kori temetö (Pitzaros-Víztározó) szisztematikus cmbertani foldolgozísa. PhD dissertation. University of Szeged, Hungary.

Molnár, E.; Horváth, G. 1995. Developmental anomalies of teeth in historic skeletal samples. In: Radlanski, R. J.; Renz, H. (eds.). Proceedings of the $10^{\text {th }}$ Intermationnl Symposinm on Dental Monphology. Berlin, 6-10 September 1995. Berlin, C. \& M. Brünne GbR: 377-385.

Molnár, E.; Marcsik, A.; Dutour, O.; Bérato, J.; Pálfi, Gy. 1998. Skeletal tuberculosis in Hungarian and French medieval anthropological material. In: Guerci, A. (ed.). La cura delle Malnttie Itinerari Storici. Genova, Erga Edizioni: 87-99.

Ortner, D. J. 2003. Itentification of pathological conditions in human skeletal remuins. $2^{\text {nd }}$ edition. San Diego, Academic Press.

Ortner, D. J.; Putschar, W. G. J. 1985. Identification of pathological conditions in human skelctal remains. Washington DC, Smithsonian Institution Press. (Smithsonian Contribution to Anthropology; 28).

Pálfi, Gy. 2002. Palaeoepidemiological reconstruction of tuberculosis, with particular attention to Europe. In: Bennike, P.; Bodzsár, E.; Susanne, C. (eds). Ecological aspects of past Human settlements in Europe. Bicminl Books of EAA. Budapest, Eötvös University Press.Vol. 2: 193210.

Pálfi, Gy.; Marcsik, A. 1999. Palaeoepidemiological data of tuberculosis in Hungary. In: Pálfi, Gy.; Dutour, O.; Deák, J.; Hutás, I. (eds.). Tuberculosis: past and present. Budapest - Szeged, Golden Book - TB Foundation: 531-539.

Resnick, D.; Niwayama, G. 1988. Dingnosis of hone and joint disortcrs. Philadelphia, W. B. Saunders Company.

Roberts, C.; Lucy, D.; Manchester, K. 1994. Inflammatory lesions of ribs: an analysis of the Terry Collection. American Journal of Physical Anthropology, 95(2): 169-182.

Santos, A. L.; Roberts, C. 2001. A picture of tuberculosis in young Portuguese people in the early $20^{\text {th }}$ century: a multidisciplinary study 
of the skeletal and historical evidence. American Joumal of Physical Anthropology, 115(1): 38-49.

Schultz, M. 2001. Paleohistopathology of bone: a new approach to the study of ancient diseases. Yenrlook of Physical Anthropology, 44: 106147.

Steinbock, R. T. 1976. Paleopathological dingnosis and interpretation. Bone diseases in ancient human populations. Springfield, Illinois, Charles C. Thomas.

Szentpéteri, J. (ed.) 2002. Archäologische Denkmäler der Awarenzeit in Mitteleuropa. Varin Arcineologica Hungarica, 13(1): 337.

Waldron, T. 1999. The paleoepidemiology of tuberculosis: some problems considered. In: Pálfi, Gy.; Dutour, O.; Deák, J.; Hutás, I. (eds.). Tuberculosis: past and present. Budapest - Szeged, Golden Book - TB Foundation: 469-475.

Zimmerman, M. R.; Kelley, M. A. 1982. Atlas of human paleopathology. New York, Praeger Publishers. 